\title{
Visual Metaphors in Pakistani Television Commercials: Its Role in Shaping Female Consumer's Perceptions about Brand Image and its Consumption
}

\author{
Sumera Batool, Moneeba Iftikhar* and Arfa Mashal \\ Department of Mass Communication, Lahore College for Women University, Lahore, Pakistan.
}

Received: September 19, 2020

Published Online: December 20, 2020

\begin{abstract}
The consumers have many choices in buying products around the world, which makes tough competition among the brands. To make the brand stand out in the market, visuals metaphors have become mandatory tools that the advertisers use. Therefore, this study aims to find the role of visual metaphors of Pakistani Television Commercials (TVCs) in shaping the perceptions of female consumers regarding brand image and its consumption as television audience. The study followed the theory of visual rhetoric and brand equity, which gives the building block in understanding the relationship of visual metaphors with consumer's perception about brand image. The qualitative method is used to scrutinize the in-depth perception by using focus group as a tool of data collection. The population of the study is female youth and 96 students participated as respondents. Results reveal that after watching TVCs, there is significant inclination and affirmative change in consumer's perception about buying the product among youngsters. It also shows that using visual metaphors benefit significantly in distinction of a brand from its competitors. The conclusive findings will help the advertisers to know the effectiveness of visual metaphors of TVCs in changing consumer's perception about the brand image and their buying pattern.
\end{abstract}

Keywords: Brand Perception, Buying Behaviour, Advertising Effectiveness, Products, Visual Rhetoric, Symbols, Images, Brand Strategy.

\section{Introduction}

Due to numerous brands of the same product, the advertisers need to create an interesting approach to make the brand stand out in the marketplace. In this regard, the visual metaphors help the brand to grab the consumer's attention and then affect the perception of the consumer. TVCs are one of the great media of advertising these days. Therefore, considering this importance level, the use of visual metaphors showed in TVCs that effect the consumer's perception toward the brand image is very important to talk about. This is because the perception of the consumer about the brand is building block of a brand's image. This is important to talk about the role of the visual metaphor of TVCs in shaping consumer's perceptions toward the brand image as a well-created metaphor can enable a brand to be reminded more positively (Shan et al., 2017).

Ang and Ching-Lim (2006) define metaphor as, "a metaphor shows similarity between two objects that one does not expect to be associated; in contrast, and non-metaphor describes the word literally". According to the American Marketing Association, a brand can be defined as 
"a name, term, sign, symbol, or design, or a combination of them, intended to identify the goods or services of one seller or group of sellers and to differentiate them from the competitors" (Kotler \& Keller, 2012). Metaphors position brand in the marketplace (Randazzo, 2006). The connection between metaphors and its consumer bases in the perception, which the buyer perceives by visualizing its metaphoric representation.

A visual metaphor is an unusual pairing of two elements that create a new meaning that neither element had alone, thus creating a new idea of visual expression (Bateman, 2014). The brand image represents a key element of this research. It is an important factor to make a brand noticeable, to differentiate it from the competitors' brand, to communicate the benefits to the target customers. The brand image leads to relationships between customers and brands and, thus, to increase the purchases (Esch et al., 2005). Therefore, the brand image clarifies its importance in the marketplace. The brand image directly relates to the sales of that brand's products. Therefore, the company's owner spends thousands of moneys to build and maintain their brand image.

From this perspective, the advertisers use many tools to build consumer perception in favour of that brand. Metaphors are widespread and often-used tools of advertisements; several studies have examined them. Today's market characterizes by a variety of products within the same category. Therefore, the consumer faces difficulties to distinguish between similar products. To establish the brand and the brand image uniquely, the main goal of the companies is to succeed in the market. To manage this, they approach the advertising agencies so that their brand's unique concept makes them stand out in the market and differentiate their brand from the competitors (Iftikhar et al., 2019).

There are many tools used in advertisements to build brands image and visual metaphors is significant one. The visual metaphor affects the mind of the consumer and grasps their attention. Metaphors create and manage the brand's personality (Ang \& Ching-Lim, 2006). Metaphors play a dominant role in modern advertising and communication. It gives customers an interesting approach to the usefulness of the product. The present study intends to know the role of visual metaphors of TVCs in shaping consumer's perceptions regarding brand image and consumption. A metaphorical advertising usually takes two dissimilar objects. Advertisement viewers need to discover the subtle connections to uncover the hidden advertising appeals (Sopory \& Dillard, 2002), which can make consumers have a deeper impression (Mcquarrie \& Mick, 2009).

In recent years, the number of metaphorical advertisements like this has been increasing (Chang et al., 2017). According to the literature data, between 1975 and 1999, the proportion of metaphorical advertising increased from 13\% to 20.1\% (Phillips \& Mcquarrie, 2002) and in 2014, it reached 64\% (Sakr, 2016). Therefore, as "the best-known example of a rhetorical figure, and the only one widely recognized among consumer researchers" (Mcquarrie \& Mick, 1999), the significant effect of the metaphor has been examined in the marketing communication (Phillips \& McQuarrie, 2009), such as to improve advertising recalls (Mcquarrie \& Mick, 2009), enhance persuasiveness and generate more positive consumer attitudes (Kim et al., 2017).

The advertising literature points out that the implicit metaphorical advertising is more likely to cause the audiences to generate cognitive inferences that are not in line with the corporate sector expectations (Delbaere, 2008), and even misunderstand the information that the 
companies want to convey to the buyers (Holyoak \& Stamenkovia, 2018). In addition, as the audiences become more familiar with various marketing methods, it is difficult for them to spend more time on advertising (Hervet et al., 2011) when simple and straightforward advertising seems to be more effective (Kim et al., 2017). Faced with this situation, the enterprises seem to be catch in a dilemma of whether or not to use the metaphors. Iftikhar and Islam (2017) studied semiotics of TVCs in Pakistan and revealed that the advertisers and communication practitioners use numerous strategies in the forms of outfits, colours, and style of these outfits depict signs. This visual depiction is metaphoric representation of the brand to attract the audience.

The objectives of this study are to know the role of the visual metaphors of TVCs in shaping the consumer's perceptions regarding the brand image and to explore the role of the visual metaphors of TVCs in the brand consumption. The study comprises of the research questions: do the visual metaphors in TVCs increase awareness of the brand? Does the use of visual metaphors in TVCs shape the perceptions of consumers about the brand image? Do the visual metaphors in TVCs play any role in the purchasing intentions of the consumers?

\section{Review of Literature}

Visual metaphors related to an indirect process of persuasion in advertising and marketing. It primarily uses metaphors tacitly to indicate advertising appeals, which is very common in advertising marketing communication. Metaphorical advertising is indeed very influential than non-metaphorical advertising. This study at first, answers the different typologies of pictorial metaphor in advertising practices. Secondly, it discovers the way visual metaphor engages the target market and prompts promising purchase action in return to the advertisements. Meanwhile, this study abridges the moderating aspects, out of these two aspects of advertising i.e., stimuli and individual's differences (Zhao \& Lin, 2019).

Visual metaphors in advertisements work as a tool to persuade the consumers towards the brands. Alousque (2015) pointed out the role of text in recognizing visual metaphor in adverts through the quantitative analysis. The findings of the survey showed that the text might serve to highlight the product quality or one of its features, thus working as a persuasive technique. Albakry and Daimin (2014) illustrated the part being frolicked by visual rhetoric in some public service print advertising extract using semiotic analysis. The study showed that the supremacy of visual rhetoric in commercials help to tie a bond with cultural gaps in social environment through visual semiotic language. Pileliene and Grigaliunaite (2016) studied to equate the impact of advertisements with and without the use of metaphors in them. The study revealed the fact that explicit traits of buyers' response to lactic product advert, has influenced by the solicitation of visual metaphors.

Mzoughi and Abdelhak (2011) analyzed the impact of stylistic elements in advertising that form visual and verbal rhetorical figures on imagery and recall. The study found that the ability of mental imagery could have been a variable contributing to strengthening the recall of advertising messages using figures of rhetoric. Cao et al. (2018) showed the liking behaviours of people of different backgrounds toward the advertisements using the visual metaphor of hybrid structure in their research study. The results showed that the visual pictures that have both similar functions and shapes rank top in all the perspectives examined, followed by those having a dissimilar shape and similar function and those having similar shape and dissimilar functions. Pawlowski et al. (2016) suggested that advertisers should be aware that the 
youngsters may have difficulty in interpreting metaphors and that metaphors may not be more effective in terms of children's recall and perception of understandability than literal versions of advertisements.

Madsen (2018) identified why viewers were attracted to visual metaphor ads and provided a better understanding of the types of consumers who view them revealing their subjective opinions and attitudes. The study suggested that visual metaphors attract a diverse audience. Advertisers may create more effective, visual metaphors to address the diversity. Muljosumarto (2018) examined colour as a "language" to convey the TVC message to the audience, using Kobayashi's Colour Image Scale. The study showed that to effectively communicate the information, perfect colour combinations could be used. Colour can communicate the content and ideas quickly without overwhelming the viewer's attention span. The colour harmony is helping the audience to understand the visual message. Aker (1997) identified brand's personality, traits, and psychology and found that understanding of the symbolic use of brands has been limited in the consumer behaviour literature.

Van-Mulken et al. (2010) tested whether consumers' experience of deviation from expectation and complexity vary with regard to three types of visual metaphor. The results showed that the hybrids were the preferred type of visual metaphor that deviations from expectation and comprehension have a positive impact on appreciation, and that perceived complexity correlates negatively with appreciation. Zhang and Gao (2009) examined the conceptual metaphor. They concluded that conceptual metaphor theory could interpret the specific persuasive roles of conceptual metaphors in commercial advertising. In advertising communication, the mapping process across conceptual domains within the conceptual metaphor is the process of the audience is searching for optimal relevance in a dynamic cognitive context and deriving the advertiser's communicative intension. Ang and Ching-Lim (2006) worked whether metaphors in advertising have a synergistic or compensatory effect on brand personality perceptions of utilitarian and symbolic products. The results suggested that metaphors could strategically be used to influence brand personality perceptions, particularly for utilitarian products.

Creating the brand image is equally important through brand image concept and brand development phases. In order to generate a solid brand image, the buyer must deliver with the planned strategic information and to generate a buyer's emotional affection with the brand, it is essential to use the company's trademark emotional stimuli (Isoraite, 2018). Bian and Moutinho (2011) studied the role of brand image, product involvement, and knowledge in explaining the consumer purchase behaviour. This research is pioneer in contributing to the literature about the counterfeits to create perceived brand identity, which plays a leading part in the brands amplification in the eyes and minds of consumer to increase their purchase intention. All is based on the brand turnover and the brand traits, whereas, involvement and knowledge have no noteworthy effect (Mehreen et al., 2020).

Benny (1982) elaborated in her study that one of the crucial factors in consumer's choice for purchase of a product is the brand image. The study reported that majority of the respondents prefer to buy branded product only when the quality is essential whereas a few are those who always buy the branded products. Kinra (2006) worked on the effects of country origin on foreign brand names in the Indian market. She found that the quality of extraneous brands professed usually advanced and grander as compared to the local brands. Most customers also related more approachability of foreign brands in the market with premium quality at fewer 
prices. For instance, in South Asia, the Indian market assessed the branded products as advanced in technology, excellence, prestige, and self-worth than India's own brands and accredited greater integrity.

There is a reasonable number of literature available on the use and effect of the visual metaphors in the print advertising but the gap in literature is for the television commercials. Considering TVCs persuasive and effective in the modern technical era where there is no one who can spurt from the surrounded environs of TV viewing. The study protracted its canvas to the role of visual metaphors in shaping perception regarding brand image and its consumption. Drawing from the review of literature, the messages conveyed through visual metaphors are more powerful. This study hypothesizes that, "the use of visual metaphors in TVCs leads to a stronger brand image" (H1).

The TVCs, which have visual metaphors, convey an influential argument in the visual modality and the metaphorical style of the rhetoric, both of which may enhance the impact of messages. The three message conditions of this study are based on the TVCs that contain nonmetaphorical (literal) visual image with the verbal argument; metaphorical visual image with verbal argument; and metaphorical image without convoying verbal argument. Cognitive elaboration, source credibility, advertisement attitude, brand attitude, product belief, and purchase intention are the important results. The outcomes of the study suggest that the visual metaphors may be more persuasive due to both the visual argumentation and the metaphorical rhetoric (Jeong, 2008).

\section{Conceptual and Theoretical Framework}

\subsection{Theory of Visual Rhetoric}

The rhetoric is an explanatory notion that mounts a message as one's effort to affect the audience. The sender's aim assumes to reveal in the form of argument, evidence, the order of argumentation, and the style of delivery. In this theory, Foss (2004) explained how to examine the nature and function of images. In this study, the theory of visual rhetoric designed to allow an approach to the visual environment from a rhetorical perspective. The rationale for using this theory is to understand the meaning and role of rhetoric images in TVCs. Foss further elaborated that "visual rhetoric" are having two meanings. First, this term uses to represent the visual object or the artefact. Here the visual rhetoric refers to the products that are created for communicating. In the second sense, visual rhetoric to focus on symbolic processes that use images to communicate.

A visual image is considered to be visual rhetoric when it is symbolic, involves human intervention, and is presented for communicating with an audience. The visual rhetoric is concerned with an appeal to a real or an ideal audience. This research study embraces the theory of the visual rhetoric in terms of use of the symbolic images in TVCs and an appeal, can be persuasive, is structured through human interaction in television advertisements. Taking assumptions from theory of visual rhetoric, the present study looked into the role of visual images of TVCs.

\subsection{Keller's Customer-Based Brand Equity Framework}

The Keller's customer-based brand equity model is related to the researcher's main objective 
to study the effect of the visual metaphor in constructing or shaping the brand image. This framework is relevant because, Kotler and Keller (2012) has said in the model, to build the relationship with the consumer, brand image is the second most important step. This model shows how a brand's success is directly attributed to the consumer's attitudes towards a brand. This model helps to understand the customer's perception about the brand, which is also the major aim of the researchers in this study.

\section{Research Methodology}

This study has inducted a qualitative approach, which has conceptual background with focus group methodology to have a good understanding about the role of visual metaphors of TVCs in shaping consumer's perceptions of brand image and its consumption. Socio-cultural factors were not the part of this study. The main objective of Brand Equity Model was to explore the potential of the visuals that are being used in TVCs are whether capable of getting attention and playing a part in decision-making or not. The study discusses visual metaphors and brand image. Ninety-six female students interviewed. All participants were females because the TVCs with strong visuals showed to the respondents were mostly female oriented and their product consumption mostly depends on visuals of advertisement. It was a cross-sectional sample in which all the respondents were from the same region but divided in groups based on their ages. In Pakistan, psychographics depends on age groups.

The participants were nominated through purposive sampling; with key selection aspects, that everyone should be young watching the latest TVCs. The respondents were university students enrolled in different academic departments of specialization; it was not possible to select them based on their cultural, social, and economic backgrounds. The researchers can conduct future quantitative studies using these factors as variables. All the participants divided into 6 groups, each consisting 16 respondents. As many as six focus groups comprising 96 participants aged $18-29$ were sampled, with each group consisting of 16 members. All discussion sessions were bilingual (English and Urdu) spanning 2 hours on average.

Table 1: General Information about Respondents

\begin{tabular}{cccccc}
\hline No. & Focus Group & Age & Time & Duration & Date \\
\hline 1 & Group 1 & $18-20$ & 9 AM - 11 AM & 2 hours & $15^{\text {th }}$ June 2020 \\
2 & Group 2 & $20-22$ & 1 PM - 3 PM & 2 hours & $15^{\text {th }}$ June 2020 \\
3 & Group 3 & $22-24$ & 9 AM - 11 AM & 2 hours & $16^{\text {th }}$ June 2020 \\
4 & Group 4 & $24-26$ & 5 PM - 7 PM & 2 hours & $16^{\text {th }}$ June 2020 \\
5 & Group 5 & $26-28$ & 9 AM - 11 AM & 2 hours & $17^{\text {th }}$ June 2020 \\
6 & Group 6 & $28-29$ & 5 PM - 7 PM & 2 hours & $17^{\text {th }}$ June 2020 \\
\hline
\end{tabular}

Healthy discussion sessions were arranged with all the groups according to the convenience and understanding of the students so that better findings can be evaluated. The participants were involved in different activities during data collection. For example, they provided with notepads and stationery to record their responses so that no point could be missed during analysis and the data could be evaluated efficiently. The discussion of Group 1 was arranged on $15^{\text {th }}$ June 2020 in the morning for 2 hours from 9 A.M. to 11 A.M. The discussion of Group 2 was arranged on $15^{\text {th }}$ June 2020 in the afternoon for 2 hours from 1 P.M. to 3 P.M. The discussion of Group 3 was arranged on $16^{\text {th }}$ June 2020 in the morning for 2 hours from 9 A.M. to 11 A.M. Group 4 discussion was arranged on $16^{\text {th }}$ June, 2020 in the evening for 2 hours from 
5 P.M. to 7 P.M. Group 5 discussion was arranged on $17^{\text {th }}$ June, 2020 in the morning for 2 hours from 9 A.M. to 11 A.M. Group 6 discussion was arranged on $17^{\text {th }}$ June, 2020 in the evening for 2 hours from 5 P.M. to 7 P.M.

\section{Analysis and Interpretation of Data}

This section of the paper deals with the analysis and interpretation of the data. Focus Groups were used to collect the data. Fifty-eight percent respondents' age was 18-24 years and fifty percent respondents' age were 24-29 years. Therefore, it can be declared that majority of the respondents were young.

\subsection{The Pre-test}

\subsubsection{Buys a Product after Watching a TVC}

In response to the purchase of a product after watching TVC, the participants of group 1 and 2 who are young, aged between 18-22 years, and are high media consumers, were of the view that an advertisement affects their perception about a product after watching a TVC and may be intended to purchase the product. Eighty percent of the participants of these groups agreed that they buy a product after watching an advertisement. TVCs have also affected the group 3 and 4 who are aged between 22-26 years but to a moderate level. They mostly preferred to analyse the rationality of the product but after analysis, $75 \%$ of the respondents mostly preferred to buy the product. In response to buying a product after watching a TVC, the participants of group 5 and 6 who are aged between 26-29 years, are adult and are mature enough to decide what to buy and what not. They were of the view that they buy the product only if the TVC attracts them with some logical visuals, which appeals them to purchase the product sixty five percent.

\subsubsection{Visual Symbols or Image Grabs the Attention while Watching TVCs}

In response to the statement of visual symbols or image, that grab the attention while watching the TVCs, the participants of group 1 and 2 who are aged between 18-22 years, were of the view that they do not get much attracted by the visual symbols and images until or unless it is some beauty product or related to the fashion. Sixty percent of the participants of these groups agreed to this statement. However, the participants of group 3 and 4 who are aged between 2226 years did not show much interest in the purchase of the product just because of visual symbols and images are not much attractive elements to purchase a product. Only fifty percent of the participants in these groups responded positively to this statement. For group 5 and 6 , who are aged between 26-29 years, added that they could not buy a product just because of the attractive images and symbols in the TVC and only forty five percent of the participants agreed to the statement.

\subsubsection{Use of Visual Images or Symbols makes the Brand Look Good}

In response to the statement that the use of visual images and symbols make the brand look good, the participants of group 1 and 2 pointed out that visual images enhance the brand image and seventy one percent of the participants agreed to the statement. Majority of the participants of group 3 and 4 responded to the statement that visual images and symbols improve the brand look and mostly persuade the viewer to buy the product and sixty seven percent of the 
participants agreed to the statement. For this statement, the participants of group 5 and 6 added that the use of visual images and symbols improves the identity of the brand and seventy-two percent of the participants responded positively.

\subsubsection{A Brand's Useful Features can be Understood by its Visual Display in TVCs}

In response to the understanding of useful features of a brand by its visual display in TVCs really did not attract the respondents. Participants of group 1 and 2 said that they do not understand the features of a product just by watching the TVC unless they do not use it. Only fifty percent of the respondents agreed to the statement. When the participants of group 3 and 4 asked about the understating of the useful features of a brand by its display in TVCs, they said that they can understand the brand's feature by the TVC but it does not appeal them. Only fifty-one percent of respondents agreed to the statement. Fifty percent of the participants of group 5 and 6 responded moderately to the statement.

\subsubsection{Visuals in TVCs Attract them to Buy that Product}

Participants of group 1 and 2 responded to the statement if they want to buy the product after watching visuals in TVCs as they somehow want to buy the product due to visuals in TVC and sixty-four percent of the respondents reacted positively. Responding to the above statement, participants of group 3 and 4 mentioned that visuals in TVCs attract them to some extent to buy a product but some were also of the opinion that they do not buy a product only relying on its TVC. Only fifty-five percent of the respondents favoured the statement. In response to buying a product because of visuals in the TVCs, participants of group 5 and 6 said that they do not much attracted towards a product only by viewing its TVC. Sixty one percent of participants agreed with the statement.

\subsubsection{People Change their Views about a Brand after Watching Visuals in TVCs}

Participants of group 1 and 2 were of the view that TVC cannot change the view about a brand and only forty two percent of the respondents of this group agreed to the statement. Responding to the statement, the participants of group 3 and 4 said that they think about a brand after watching visuals in its TVC and forty eight percent of the participants agreed to the statement. In response to the statement, majority of the participants of group 5 and 6 stated that they could not change their views about a brand just because of the visuals of its TVC and fifty percent of the participants agreed to the statement.

\subsubsection{Using Symbol or Image can Differentiate a Brand from its Competitors}

In response to this statement, the participants of group 1 and 2 showed positive response and seventy percent of the respondents agreed that the symbols play in important role in making a brand stand out among its competitors in the market. The participants of group 3 and 4 were also of the view that the unique symbols and images differentiate a brand from its competitor product but few people also disagreed to the statement. Seventy five percent of the participants agreed with the statement. Responding to the statement, the participants of group 5 and 6 stated that they give an importance to the visuals and the images shown in a brand's TVC which makes it unique than its similar or competitor brands and seventy seven percent of the participants agreed with the statement. 


\subsubsection{Visual Symbol or Image can be Described as a Strategy of Brand Image Creation}

The Participants of group 3 and 4 showed great interest in this block and responded massively. Majority of the participants had the view that visual symbols play an important role in brand image creation. Seventy two percent of the participants agreed to the statement. Responding to the above statement, participants of group 5 and 6 who are mature and adult and can understand the concept of brand image strategy in a better way immensely agreed to the statement and the positive response was seventy-five percent.

Table 2: Students Comments on Role of Visual Metaphors of TVCs in Shaping Consumer's Perceptions of Brand Image and its Consumption

\begin{tabular}{llc}
\hline \multicolumn{1}{c}{ Block } & \multicolumn{1}{c}{ Main Quotes } & $\begin{array}{c}\text { \% of Total } \\
\text { Mentions }\end{array}$ \\
\hline Buys a product after watching a TVC & $\begin{array}{l}\text { I think TVC persuades mind to buy a } \\
\text { product }\end{array}$ & $66 \%$ \\
\hline $\begin{array}{l}\text { Visual symbols or image grab the } \\
\text { attention while watching TVCs }\end{array}$ & $\begin{array}{l}\text { Visual symbols attracts the attention and } \\
\text { persuades to buy the product }\end{array}$ & $59 \%$ \\
\hline $\begin{array}{l}\text { Use of visual images or symbols make } \\
\text { the brand look good }\end{array}$ & $\begin{array}{l}\text { I think visual images help in creating the } \\
\text { image of the brand }\end{array}$ & $70 \%$ \\
\hline $\begin{array}{l}\text { A brand's useful features can be } \\
\text { understood by its visual display in TVCs }\end{array}$ & $\begin{array}{l}\text { A TVC highlighting the features grabs } \\
\text { the attention to buy the product }\end{array}$ & $49 \%$ \\
\hline $\begin{array}{l}\text { Visuals in TVCs attract them to buy that } \\
\text { product }\end{array}$ & $\begin{array}{l}\text { I think I would prefer to buy a product } \\
\text { due to the attractive features in its TVC }\end{array}$ & $60 \%$ \\
\hline $\begin{array}{l}\text { People change their views about a brand } \\
\text { after watching visuals in its TVC }\end{array}$ & $\begin{array}{l}\text { Visuals in a TVC change the views } \\
\text { about the brand }\end{array}$ & $50 \%$ \\
\hline $\begin{array}{l}\text { Using symbol or image can differentiate } \\
\text { brand from its competitors }\end{array}$ & $\begin{array}{l}\text { Symbols and images make the brand } \\
\text { look unique and stand out }\end{array}$ & $77 \%$ \\
\hline $\begin{array}{l}\text { Visual symbol or image can be described } \\
\text { as a strategy of brand image creation }\end{array}$ & $\begin{array}{l}\text { I think visual symbols and images } \\
\text { creates an image of the brand }\end{array}$ & $70 \%$ \\
\hline
\end{tabular}

\subsection{The Post-test}

\subsubsection{Buys a Product after Watching a TVCs}

In response to the purchase of a product after watching TVC, the participants of group 1 and 2 who are young and aged between 18-22 years, are high media consumers were of the view that an advertisement affects their perception about a product after watching a TVC and are intended to purchase the product. Eighty five percent of the participants of this group agreed to buy a product after watching an advertisement. TVCs have also greatly affected group 3 and 4 who are aged between 22-26 years. They mostly analyse the rationality of the TVC but after analysis, eighty-three percent of the respondents mostly preferred to buy the product. In response to buying a product after watching a TVC, the participants of group 5 and 6 who are aged between 26-29 years, adults and mature enough to decide what to buy and what not. They were also of the view that they buy the product only if the TVC is attractive enough to purchase the product eighty percent.

\subsubsection{Visual Symbols or Image Grabs the Attention while Watching TVCs}

In response to the visual symbols or image, grab the attention while watching TVCs, participants of group 1 and 2, were of the view that the visual symbols and images in a TVC 
attract them especially if it related to fashion. Eighty five percent of the participants agreed to the statement. For this statement, the participants of group 3 and 4 showed interest in the purchase of the product just because of visual symbols and images, which are attractive elements to purchase a product. Ninety percent of the participants responded positively towards this statement. For group 5 and 6 added that they could buy a product just because of the attractive images and symbols in the TVC and eighty eight percent of the participants agreed to the statement.

\subsubsection{Use of Visual Images or Symbols Makes the Brand Look Good}

In response to the statement that the use of visual images and symbols make the brand look good, participants of group 1 and 2 pointed that visual images enhances the brand image and $75 \%$ of the participants agreed to the statement. Majority of the participants of group 3 and 4 responded to the statement that visual images and symbols improve the brand look and mostly persuade the viewer to buy the product and eighty percent of the participants agreed to the statement. For this statement, the participants of group 5 and 6 added that use of visual images and symbols improves the identity of the brand and seventy-three percent of the participants responded positively.

\subsubsection{A Brand's Useful Features can be Understood by its Visual Display in TVCs}

In response to the understanding of useful features of a brand by its visual display in TVCs attracted the respondents. Participants of group 1 and 2 said that they understand the features of a product just by watching the TVC. Eighty seven percent of the respondents agreed to the statement. When the participants of group 3 and 4 asked about the understating of the useful features of a brand by its display in TVCs, they said that they can understand the brand's feature by the TVC and it appeals them to buy it. Ninety one percent of the respondents agreed to the statement. Participants of group 5 and 6 responded interestingly to the statement mostly. Ninety percent of the participants agreed to the statement.

\subsubsection{Visuals in TVCs Attract them to Buy that Product}

The participants of group 1 and 2 responded to the statement that when they wish to buy the product, their intention is based only due to its visuals and the way it presented in the TVC and ninety-five percent of the respondents reacted positively. Responding to the above statement, the participants of group 3 and 4 mentioned that visuals in TVCs attract them to great extent to buy a product but very few were of the opinion that, they do not buy a product relying only on its TVC. Eighty eight percent of the respondents favoured the statement. In response to buying a product because of visuals in the TVCs, participants of group 5 and 6 said that they get much attracted towards a product only by viewing its TVC. Ninety percent of the participants agreed with the statement.

\subsubsection{People Change their Views about a Brand after Watching Visuals in TVCs}

The participants of group 1 and 2 were of the view that TVC play an important role in changing their view about a brand and eighty-eight percent respondents of these groups agreed to the statement. Responding to the statement, the participants of group 3 and 4 responded that they think about a brand after watching the visuals in its TVC, which makes them buy the product as well, and eighty three percent of the participants agreed to the statement. In response to the 
statement, majority of the participants of group 5 and 6 stated that they change their views about a brand just because of the visuals of its TVC and ninety percent of the participants agreed to the statement.

\subsubsection{Using Symbols or Image can Differentiate a Brand from its Competitors}

In response, the participants of group 1 and 2 showed positive response towards the statement and eighty percent of the people agreed that symbols play in important role in making a brand stand out among its competitors. Participants of group 3 and 4 were also of the view that unique symbols and images differentiate a brand from its competitor but few people also disagreed to the statement. Seventy nine percent of the participants agreed with the statement. Talking about the statement, participants of group 5 and 6 stated that they give importance to the visuals and images shown in a brand's TVC which makes it unique than its similar brands and eighty four percent of the participants agreed with the statement.

\subsubsection{Visual Symbols or Image can be Described as a Strategy of Brand Image Creation}

The young participants of group 1 and 2 responded interestingly to this statement after having understanding about image creation and eighty eight percent of the participants responded positively about the statement. Participants of group 3 and 4 showed great interest in this block and responded massively. Majority of the participants had the view that visual symbols play an important role in brand image creation. Ninety one percent of the participants agreed to the statement. Responding to the above statement, participants of group 5 and 6 who are mature and adult and can understand the concept of brand image strategy in a better way immensely agreed to the statement and the positive response was ninety percent. The study aimed to examine the use of visual metaphors of TVCs in effecting consumer's perception toward the brand image. For this purpose, the researcher designed different blocks that can affect consumer's perception about a brand. The responses found in the focus group discussion mentioned here in the light of selected data.

Table-3: Students Comments on Role of Visual Metaphors of TVCs in Shaping Consumer's Perceptions of Brand Image and its Consumption

\begin{tabular}{llc}
\hline Block & Main Quotes & $\begin{array}{c}\% \text { of Total } \\
\text { Mentions }\end{array}$ \\
\hline Buys a product after watching a TVC & $\begin{array}{l}\text { I think TVC persuades mind to buy a } \\
\text { product }\end{array}$ & $80 \%$ \\
\hline $\begin{array}{l}\text { Visual symbols or image grab the attention } \\
\text { while watching TVCs }\end{array}$ & $\begin{array}{l}\text { Visual symbols attracts the attention and } \\
\text { persuades to buy the product }\end{array}$ & $87 \%$ \\
\hline $\begin{array}{l}\text { Use of visual images or symbol makes the } \\
\text { brand look good }\end{array}$ & $\begin{array}{l}\text { I think visual images help in creating the } \\
\text { image of the brand }\end{array}$ & $79 \%$ \\
\hline $\begin{array}{l}\text { A brand's useful features can be } \\
\text { understood by its visual display in TVCs }\end{array}$ & $\begin{array}{l}\text { A TVC highlighting the features grabs } \\
\text { the attention to buy the product }\end{array}$ & $88 \%$ \\
\hline $\begin{array}{l}\text { Visuals in TVCs attract them to buy that } \\
\text { product }\end{array}$ & $\begin{array}{l}\text { I think I would prefer to buy a product } \\
\text { due to the attractive features in its TVC }\end{array}$ & $92 \%$ \\
\hline $\begin{array}{l}\text { People change their views about a brand } \\
\text { after watching visuals in its TVC }\end{array}$ & $\begin{array}{l}\text { Visuals in a TVC change the views } \\
\text { about the brand }\end{array}$ & $85 \%$ \\
\hline $\begin{array}{l}\text { Using symbol or image can differentiate a } \\
\text { brand from its competitors }\end{array}$ & $\begin{array}{l}\text { Symbols and images make the brand } \\
\text { look unique and stand out }\end{array}$ & $82 \%$ \\
\hline $\begin{array}{l}\text { Visual symbol or image can be described } \\
\text { as a strategy of brand image creation }\end{array}$ & $\begin{array}{l}\text { I think visual symbols and images } \\
\text { creates an image of the brand }\end{array}$ & $90 \%$ \\
\hline
\end{tabular}




\section{Conclusion}

The study took the visual metaphors as a subject of brand perception and the findings show that the visual metaphors in TVCs highly effect the young female consumer's perception towards the brand image. The results show that the TVCs have great influence on the consumer's mind. The analysis shows that most of the respondents buy a product after watching TVCs and the main reason is the catchy visuals that fascinate them about the product. The findings of the study reveal that the use of visual metaphors highly clutches the attention of female youth and they mostly spectacle a positive response after watching the TVCs. The corporations use different pleas to form consumer's perception in liking a product. The usage of visual metaphors increases cognizance about the brand and it leaves a positive impression on consumer's mind.

The respondent female youth during group discussion shared that visual metaphors in advertising is a significant strategy in the creation of positive brand's image. The study also reveals that consumer's views about brand changes after watching TVCs. This exploratory study found the co-relation of audience minds and visual metaphors, which serve as good addition to literature in the context of Pakistani advertising. Further investigation can continue in quantitative studies to scrutinize the effects of these metaphors on audience in terms of social behaviour and construction of social realities.

\section{References}

Aker, J. L. (1997). Dimensions of brand personality. Journal of Marketing Research, 34 (3), 347-356. https://doi.org/10.1177/002224379703400304

Albakry, N. S., \& Daimin, G. (2014). The visual rhetoric in public awareness print advertising toward Malaysia perceptive socio-cultural design. Procedia-Social and Behavioural Sciences, 155, 28-33. https://doi.org/10.1016/j.sbspro.2014.10.251

Alousque, I. N. (2015). The role of text in the identification of visual metaphor in advertising. Procedia-Social and Behavioural Sciences, 212, 309-315. https://doi.org/10.1016/j.sbspro.2015.11.379

Ang, S. H., \& Ching-Lim, E. A. C. (2006). The influence of metaphors and product type on brand personality perceptions and attitudes. Journal of Advertising, 35(2), 39-53. https://www.tandfonline.com/doi/abs/10.1080/00913367.2006.10639226

Bateman, J. (2014). Text and Image: a critical introduction to the visual/verbal divide. Routledge. https://www.taylorfrancis.com/books/9781315773971

Benny, R. B. (1982). Influences of brand name and packaging on perceived quality. NA $\begin{array}{llll}\text { Advances in } \text { Consumer Research, 972-477. } & \text { 9. }\end{array}$ https://www.acrwebsite.org/volumes/6050

Bian, X., \& Moutinho, L. (2011). The role of brand image, product involvement, and knowledge in explaining consumer purchase behaviour of counterfeits. European Journal of Marketing, 45(1/2), 191-216. https://doi.org/10.1108/03090561111095658

Cao, S., Wang, H., \& Zou, X. (2018). The effect of visual structure of pictorial metaphors on advertisement attitudes. International Journal of Marketing Studies, 10(4), 60-71. https://doi.org/10.5539/ijms.v10n4p60

Chang, C. T., Wu, Y. C., Lee, Y. K., \& Chu, X. Y. (2018). Right metaphor, right place: choosing a visual metaphor based on product type and consumer 
differences. International Journal of Advertising, 37(2), 309-336. https://www.tandfonline.com/doi/full/10.1080/02650487.2016.1240468

Delbaere, M. (2008). Knowledge transfer and rhetoric: the influence of rhetorical figures on consumer learning. $\mathrm{PhD}$ Thesis, The University of Manitoba. https://central.baclac.gc.ca/.item?id=NR49100\&op=pdf\&app=Library\&oclc number $=708724832$

Esch, F. R., Wicke, A. \& Rempel, J. E. (2005b). Herausforderungen und Aufgaben des Markenmanagements. In Esch, F. R. (ed.) Moderne Markenfuhrung. Grundlagen Innovative Ansatze - Praktische Umsetzungen. Springer Fachmedien, 3-55. https://doi.org/10.1007/978-3-8349-4541-9_1

Foss, S. K. (2004). Theory of visual rhetoric. Handbook of Visual Communications. Routledge. https://www.routledgehandbooks.com/doi/10.4324/9781410611581.ch9

Hervet, G., Guerard, K., Tremblay, S., \& Chtourou, M. S. (2011). Is banner blindness genuine? eye tracking internet text advertising. Applied Cognitive Psychology, 25(5), 708-716. https://onlinelibrary.wiley.com/doi/abs/10.1002/acp.1742

Holyoak, K. J., \& Stamenkovic, D. (2018). Metaphor comprehension: a critical review of theories and evidence. Psychological Bulletin, 144(6), 641-671. http://reasoninglab.psych.ucla.edu/KH\%20pdfs/Holyoak_Stamenkovic.2018.pdf

Iftikhar, M., \& Islam, M. (2017). Construction of female identity in Pakistani television commercials (November, 2015-April, 2016): a semiotic analysis. Pakistan Journal of Gender Studies, 14(1), 81-110. https://socialsciencejournals.pjgsws.com/index.php/PJGS/article/view/142/93

Iftikhar, M., Mahmood, T., \& Asad, A. (2019). The use of advertising appeals and women delineation in breast cancer related web advertisements: a semiotic analysis of western and eastern advertising. Global Regional Review, 4(1), 480-497. https://grrjournal.com/jadmin/Auther/31rvIolA2LALJouq9hkR/Onq2dvihUq.pdf

Isoraite, M. (2018). Brand image development. Ecoforum Journal, 7(1). http://www.ecoforumjournal.ro/index.php/eco/article/view/704/448.

Jeong, S. H. (2008). Visual metaphor in advertising: is the persuasive effect attributable to visual argumentation or metaphorical rhetoric? Journal of Marketing Communications, 14(1), 59-73. https://doi.org/10.1080/14697010701717488

Johansson, J., Folkesson, O., \& Henningsson, J. (2018). Brand image in the sharing economy: an exploratory study of how to achieve positive customer perceptions in the sharing economy. http://urn.kb.se/resolve?urn=urn:nbn:se:hj:diva-39695

Kim, S., Kim, J., \& Kim, E. (2017). Metaphor as visual thinking in advertising and its effects: focus on brand familiarity and product involvement. Journal of Promotion Management, 23(5), 654-672. https://doi.org/10.1080/10496491.2017.1297982

Kinra, N. (2006). Effect of country origin on foreign brands names in Indian market. Journal of Marketing Practices, 24(1), 15-30. https://doi.org/10.1108/02634500610641534

Kotler, P. \& Keller, K. L. (2012). Marketing management. Prentice Hall.

Madsen, M. J. (2018). A Q-method study of visual metaphors in advertising. http://hdl.lib.byu.edu/1877/etd10189

McQuarrie, E. F., \& Mick, D. G. (1999). Visual rhetoric in advertising: text-interpretive, experimental, and reader-response analyses. Journal of Consumer Research, 26(1), 37-54. https://doi.org/10.1086/209549

McQuarrie, E. F., \& Mick, D. G. (2009). A laboratory study of the effect of verbal rhetoric versus repetition when consumers are not directed to process advertising. International Journal of Advertising, 28(2), 287-312. https://doi.org/10.2501/S0265048709200576 
Mehreen, K., Roshan, R., \& Gul, M. (2020). Psychological factors influencing the adoption of web-based shopping behaviour of female consumers. Liberal Arts \& Social Sciences $\begin{array}{llll}\text { International Journal } & \text { (LASSIJ), }\end{array}$ https://doi.org/10.47264/idea.lassij/3.2.19

Muljosumarto, C. (2018). A Case Study Color as a visual language: focused on TV commercial. Nirmana, 17(1), 1-9. https://doi.org/10.9744/nirmana.17.1.1-9

Mzoughi, N., \& Abdelhak, S. (2011). The impact of visual and verbal rhetoric in advertising on mental imagery and recall. International Journal of Business and Social Science, 2(9). $\quad$ http://ijbssnet.com/journals/Vol._2_No._9_[Special_Issue__May_2011]/30.pdf

Pawlowski, D. R., Badzinski, D. M., \& Mitchell, N. (1998). Effects of metaphors on children's comprehension and perception of print advertisements. Journal of Advertising, 27(2), 83-98. https://doi.org/10.1080/00913367.1998.10673554

Phillips, B. J., \& McQuarrie, E. F. (2002). The development, change, and transformation of rhetorical style in magazine advertisements 1954-1999. Journal of Advertising, 31(4), 1-13. https://doi.org/10.1080/00913367.2002.10673681

Phillips, B. J., \& McQuarrie, E. F. (2009). Impact of advertising metaphor on consumer belief: delineating the contribution of comparison versus deviation factors. Journal of Advertising, 38(1), 49-62. https://doi.org/10.2753/JOA0091-3367380104

Pileliene, L., \& Grigaliunaite, V. (2016). Effectiveness of visual metaphor in milk advertising. In Economic science for rural development: proceedings of the $17^{\text {th }}$ international scientific conference, Jelgava, 21-22 April 2016. No. 43: New dimensions in the development of society marketing and sustainable consumption finance and taxes. Latvian University of Agriculture. https://hdl.handle.net/20.500.12259/31922

Randazzo, S. (2006). Subaru: the emotional myths behind the brand's growth. Journal of Advertising Research, 46(1), 11-17. https://doi.org/10.2501/S002184990606003X.

Sakr, A. (2016). The effect of visual metaphor on advertising response: an integrative framework. $\mathrm{PhD} \quad$ Thesis, Aston University. http://publications.aston.ac.uk/id/eprint/30075/

Shan, C., Mingyang, Y., \& Xue, K. (2017). Effects of metaphor advertising on brand extension evaluation: construal level as mediator. Social Behaviour \& Personality: An International Journal, 45(6), 967-985. https://doi.org/10.2224/sbp.5962

Sopory, P., \& Dillard, J. P. (2002). The persuasive effects of metaphor: a meta-analysis. Human Communication Research, 28(3), 382-419. https://doi.org/10.1111/j.1468$\underline{\text { 2958.2002.tb00813.x }}$

Van-Mulken, M., Le Pair, R., \& Forceville, C. (2010). The impact of perceived complexity, deviation and comprehension on the appreciation of visual metaphor in advertising across three European countries. Journal of Pragmatics, 42(12), 3418-3430. https://doi.org/10.1016/i.pragma.2010.04.030

Zhang, X., \& Gao, X. (2009). An analysis of conceptual metaphor in Western commercial advertisements. Asian Social Science, 5(12), 97-104. https://doi.org/10.5539/ass.v5n12p97

Zhao, H., \& Lin, X. (2019, September). A review of the effect of visual metaphor on advertising response. In The 4th International Conference on Economy, Judicature, Administration and Humanitarian Projects (JAHP 2019). Atlantis Press. https://doi.org/10.2991/jahp-19.2019.7 